\title{
Muhammadiyah's Response to Climate Change and Environmental Issues: Based on Tarjih National Conference
}

\author{
Mohammad Ikhwanuddin ${ }^{1 *}$ \\ ${ }^{1}$ Department of Islamic Family Law, Muhammadiyah University of Surabaya, Surabaya, Indonesia \\ *Corresponding author. Email: mohammadikhwanuddin@fai.um-surabaya.ac.id
}

\begin{abstract}
This paper aims to analyze Islamic dialectics in the Muhammadiyah community for responding to climate change and environmental issues. As one of the institutions in Muhammadiyah, the Majelis Tarjih and Tajdid (MTT) has an important role in bridging environmental issues into the Muslim community. The National Conference Meeting in 2014 and 2015, MTT concerning fatwa about Water Jurisprudence and Disaster Jurisprudence. By the content analysis method, these two fatwas respond to various problems caused by weather changes. The fatwa serves a legal guide for programs and sustainable activities related to environmental issues. The conclusion of the paper made Muhammadiyah has shifted from a theoretical understanding of environmental preservation (Hifz al-Biah) to an active and practical attitude in translating fiqih to the level of real practice.

Keywords: Muhammadiyah, Tarjih, climate change, environmental issues
\end{abstract}

\section{INTRODUCTION}

Environmental issues have long been serious discussion among religious people. Environment is in the corridor of intermediaries and human ritual locus in carrying out the role of servitude to God. Presumably, this has become a concern for some Islamic scholars, so that some jurists gave their own consideration regarding the environment, becoming a separate part of some of the objectives of Islamic law [1].

Awareness of this environment is also directed at the contemporary situation that is being faced by humans, including the population of Indonesia. Various environmental crises have caused religious leaders to begin to re-examine authoritative sources to get a new spirit about environment-friendly diversity.

In a water crisis, for example, one of the leading mass media in Indonesia, Kompas, once reported news that was quite surprising [2]. The clean water crisis is becoming an increasingly serious problem. The need is increasing, while raw water sources are limited. Without planning and efforts to find new sources, the water deficit is increasing especially in Java. Java Island, which covers only 7 percent of Indonesia's total area, is inhabited by 65 percent of Indonesia's population, but only has 4.5 percent freshwater potential from national potential.

Several years earlier, this water crisis was also a serious concern. As reported by William Houston, that the availability of water that we have is limited, meaning that water resources have certain limitations. Meanwhile, 97\% of the water available on earth is sea water that cannot be used for drinking. Only $2.5 \%$ of the water on earth is fresh water, and only $1 \%$ is available for drinking water. The remaining $2 \%$ is polar ice and glaciers [3].
Based on that anxiety, one of the institutions in the Muhammadiyah Muslim community organization, Majelis Tarjih and Tajdid, held the 28th Tarjih National Conference, at the Muhammadiyah University of Palembang, February 27 - March 1, 2014, where one of the important decisions in the deliberation was Water Jurisprudence [4].

The decision on the results of the Tarjih National Deliberation has also been followed by the Muhammadiyah Central Leadership Decree No.101 / KEP / I.0 / B2015 concerning Tanfidz XXVIII Tarjih National Assembly Decree signed by the then Chairman of the PP Muhammadiyah Din Syamsuddin. In the line of decision bureaucracy in Muhammadiyah, the decision of the National Conference that has been signed has become an organizational decision that is binding for Muhammadiyah community.

This response to environmental issues in the form of water is the opening point in understanding environmental theology being developed by Muhammadiyah. Moreover, in the next national meeting, the 29th Tarjih National Conference in the LPMP Building (Institute for Educational Quality Assurance) in Yogyakarta, resulted in one of the decisions of the National Assembly which had awareness and sensitivity to Indonesia's geography, in the form of a decision on Disaster Jurisprudence [4].

\section{RESULTS AND DISCUSSION}

Both the decision on fatwa tarjih in the form of Water Jurisprudence and Disaster Jurisprudence provide theological reflections that can be taken care of and 
explored, to understand the awareness and concepts of environmental theology being built by Muhammadiyah.

\subsection{From Water Jurisprudence to Environmental Awareness}

Before discussing further, it is necessary to convey in advance that the fiqh term introduced by Muhammadiyah has a shift in meaning from what is commonly used by the majority of Muslim scholars. Therefore, this starting point needs to be known in advance so as not to become the initial mistake in starting the footing.

Jurisprudence which is being initiated by Muhammadiyah is defined as a set of basic values (al-Qiyam al-Asasiyyah), Universal Principles (al-Usul al-Kulliyyah) and law branches (al-Ahkam al-Far'iyyah) originating from Islam[4, pp. viii-ix]. This do not only trace the study more philosophically-reflective than limited to takli $>$ fi $>$ law, such as halal-haram, which is part of its implementation formula.

In the decision of the results of the National Conference on Water Jurisprudence, the basic values in water management are Tauhid, Gratitude, Justice ( $a d l)$, Moderation and Balance (wasatiyyah and tawazun), Leaving the unuseless (al-Fa'aliyah), Concern (al-Inayah).

The foundation of monotheism which is put into the main discussion is not merely the tendency of Muhammadiyah in the purification of Islam. Not entirely wrong, but what Muhammadiyah wants, as the contents of the verdict, is the manifestation of the vision of human unity with nature before the creator. With this vision, Muslims can realize that humans and water are parts of the universe and their existence is regulated by revelation. The principle of tauhid creates motivation and involvement (knowledge) of religion and morals, which are strong to protect and regulate water. The involvement of religion in water management, specifically, and the environment in general, actually sues human exploitative actions on the environment. The action, according to Ahmad Khoirul Fata, evolved from the tendency to place humans into the midpoint of the study epicenter. The anthropocentric tendency of man over nature, especially with the status of the "caliph" attached to it as if it were the legitimacy of the authoritative power of humans to the environment [5].

Furthermore, the legitimacy that is closely related to the act of exploitation will actually injure human diversity in the presence of the creator. The basic value which is the formulation of Water Jurisprudence teaches the transcendental role above the involvement of discussion space between humans and the environment.

However, the involvement of the transcendental dimension is not merely reaffirming humanity's authoritarianism over nature, or pursing in human ecology solely as Alim Roswantoro's words, but more than that, the relations formed between the two form a harmonious dimension of religiosity, thus forming religious or religious relations theological ecology [6].

Actually, the nomenclature of the theology of the environment itself has not been agreed with the standard definition, however, it seems that there is a meeting point of discussion, as Robert $\mathrm{J}$ Jacobus provides a meeting point that "Environmental theology is generally used to describe the physical-spiritual world-views and associated ethics" [7].

Therefore, discussing environmental theology will inevitably involve the spiritual dimension which is associated with an ethical basis. This basic ethical base described by Abdul Quddus becomes three principles in the form of Tawhid (unity of all beings), Amanah-Khalifah (honesty-leadership) and Akhirah (responsibility) [8].

The Tauhid principle introduced by Abdul Quddus shows the unity of beings alone, but the desired Tawhid in the formulation of Water Jurisprudence tends to see it in the transcendental dimension. Tauhid is not tauhid al-khalq but the tauhid of Allah.

In the next principle, namely justice, placing human position with the environment in balance and equilibrium relations so as to form a harmonious pattern. This refers to a fact, that the environment is basically part of basic human needs, even as water, manifests itself as one of human rights, like UN Resolution No.64/292 was adopted in 2010 explicitly says that water is a human right.

On the balance of environmental management, this basic value balances the potential availability of natural resources with existing needs. When needs are higher than resource availability, a crisis will occur. Therefore, placing the environment on the edge of two pendulums that are opposite each other becomes a matter of concern.

At this point, the stratification of "humans" is actually already on par with the environment. Humans are no longer at the "peak" thus legitimizing exploitative actions, but are equated with the environment, in the position of khalq (beings) before the Khaliq (Allah the Creator).

Actually, there are those who actually view that human position is not equivalent to the environment, but under the environment. The concept of Theofani Nasr, as reviewed by Maftuhin, imagines nature as a mirror of God's presence [9]. Therefore, the position of nature should be more noble compared to humans, because humans must be friends with and through nature first to disperse God.

The author point of view about nature / environment becomes a reflection of the presence of God instead of positioning humans under it, because the creation of al-kaun (universe), including human beings, is part of the mirror of God's presence in the universe. So, positioning humans in an egalitarian position with the environment, for the writer, feels more appropriate.

This attitude is one of the estuary points of Water Jurisprudence, where awareness of the environment becomes an inseparable part of the religious community, that spirituality in religion can create a beautiful and harmonious relationship with the environment based on ethical values.

\subsection{Environmental Theology of Muhammadiyah: Between Ideas and Practices}

As has been discussed in the process of environmental awareness of Water Jurisprudence, several principles which later emerged precisely laid theology not only at the level of belief and consciousness. But it needs to manifest in real actions and actions. 
Muhammadiyah was founded and developed, initially, not in the development of thought situations. But it is aimed at real and applicable actions on religious formulations into social behavior. Because of that attitude, the Muhammadiyah movement is often summarized in 3 words: feeding (compensation and empowerment), schooling (education), and healing (treatment and health) [10].

At the practical level, there are several formulations in Water Jurisprudence which can be translated into several active principles of Environmental Management, namely in the form of public involvement (musyarakat al-mujtama'), priority setting (tanzim al-awlawiyyat), conservation (almuhafadzah), ownership regulation (nizam al-milkiyyat), and distribution regulations (nizam al-tauzi') [4].

All elements of society, both civil and government, have the same obligations. The participatory approach is one of the important meanings of belonging in managing the nation's wealth. This is not only important in terms of similarity of views / perceptions, but also becomes a concurrent and rhythmic action in the process of environmental management.

Communities that have authority in water management must have the same perception of where the environment is lived/carried out. Therefore, to avoid exploitation of increasingly wild environments, a mapping related to priority scale to avoid waste and over-exploitation.

The preparation of the priority scale in the use of the environment, for example, can reflect on the hierarchy of needs contained in the concept of syariah. Human needs in the use of water, for example, can be translated into three things, namely primary needs (al-daruriyyah), secondary needs (al-hajiyyah), and tertiary needs (al-tahsiniyyat).

Basically, human needs for the environment can also be divided into three levels, and its implementation also prioritizes scale. In the view of Islam, natural resources (SDA) in its essence belong to Allah which is mandated to manage, use, and preserve it to humans Management, exploration and exploitation of natural resources must pay attention to the preservation of nature, the environment and the sustainability of development. Management of natural resources needs to pay attention to the carrying capacity and capacity of the environment and socio-cultural community, to achieve economic and ecological efficiency (ecoefficiency) by applying environmentally friendly technologies and methods. That environmentally friendly way is translated into environmental morals [11].

Through the resources they have, environmental morals can be applied in the insertion of the learning process, giving examples, habituation, reflection on the community regarding the management and preservation of the environment [12].

This preservation is also the starting point of all environmental conservation activities. As a confirmation it is interpreted as an effort to regulate the environment so that it remains a quality and progressive resource, conservation ensures the availability of natural resources in the future. So that future generations can still manage the environment properly.

Therefore, one of the central roles here is the government in regulating environmental ownership, namely the regulation of ownership of resources that are in the environment, both by the public and individuals by not opening the doors of privatization and baseless monopoly [4]. Included in the regulation here is the regulation of distribution in the use of the environment.

Refusing to the basic values and universal principles above, preventing and handling crises is the duty of every Muslim. Therefore, damaging the environment in a particular ecosystem has an impact on other ecosystems, and the law is haram.

\subsection{Fulfilling Environmental Theology with Disaster Jurisprudence}

Disaster in the editors of Islam is often referred to as Musibah. Disasters sometimes result in loss, damage, and destruction (tadmir, tamziq), or paralyzed social functions (halak and fasad), and chaos. For further diction about "musibah" in several verse in Quran and Hadis can be read in [4].

The disaster comes from God's provisions, and is God's test of his servant. Therefore, responding to disasters must be positively limited by not blaming God and prejudicing Him. This attitude must also be accompanied by efforts to escape from the disaster and not despair of God's grace and have the spirit to rise again.

People who are victims of disasters must have a belief and trust about the solidarity of others. Still have hope for the future, and life optimism is a key word in responding to disasters [4].

Disaster in essence is not a disaster for people who are directly affected / become victims, but also disasters for others. Therefore, it is a common obligation for the community to provide assistance in accordance with the minimum standards for fulfilling the rights of disaster victims. The concept of humanitarian assistance for victims of disasters is no longer an activity of giving donations (charity), or activities that are oriented towards the desires of aid providers and merely the needs of affected people. But the assistance must be oriented towards empowerment, fulfillment of the rights of human life, and participation by seeking conditions that must be achieved in all humanitarian actions so that the affected population can survive and recover to a stable and dignified condition.

Disaster Jurisprudence is the formulation of Muhammadiyah's concern for the misery of others. Although disasters are not always associated with the environment, Indonesia's geographical conditions place Indonesia in a disaster-prone situation. Because of this situation of vulnerability, understanding of environmental awareness needs to be strengthened, mitigation alertness and reliability need to be improved. Because disasters that come often cause many casualties, both in terms of soul and material.

Some of the action activities both mitigation and recovery are carried out by Muhammadiyah not only or the basis of an in-depth understanding of Disaster Jurisprudence, but also on the principle of the ethos of Muhammadiyah in developing social sensitivity in its charitable activities.

Actually, the base of this attitude can be traced when Muhammadiyah begins to define religion as everything that Allah has revealed in the Koran, and that is in al-Sunnah alMaqbulah (received) in the form of orders, prohibitions, and 
instructions -guide (al-irsyad) for the good of mankind in the world and in the hereafter [13].

At this level, M.B Hooker views that:

"The foundation of the Muhammadiyah ideology: (a) lies in the idea of maqasid al-shari'a that is, that law has a purpose, an objective which must be identified and implemented; (b) the purpose is maslaha, public interest! widely defined benefits [14]. In the principle of benefit and definition of religion, it seems that the perspective on disaster becomes normativity. That disaster, whatever its form, is actually a form of God's love for humans [4].

This perspective is not merely driven by textual truth, in which Imam al-Bukhary once narrated the hadith "Who is God who wants good, then he will be tested (yus $\}$ ab, given calamity) from Allah".

Therefore, in the Muhammadiyah Citizens' Islamic life guidelines, the interrelated attitudes between environmental awareness and disaster alertness can be formulated as follows [15]:

a. The environment as a natural environment with all the contents contained in it is a creation and gift of God that must be processed / prospered, maintained, and may not be damaged.

b. Every Muslim, especially Muhammadiyah citizens, is obliged to conserve natural resources and their ecosystems, so that ecological processes are maintained that support survival, the maintenance of genetic diversity and various types of ecosystems and controlled methods of natural resource management. So that preserved the continuity and sustainability for the sake of safety, happiness, well-being, and human survival and the balance of living systems in this universe.

c. Every Muslim, especially Muhammadiyah residents, is prohibited from carrying out efforts and actions that cause damage to the natural environment, including biological life such as animals, trees, and physical and biotic environments including seawater, air, rivers, etc. which cause a loss of ecosystem balance and the emergence of disasters in life.

d. To socialize and practice clean culture; healthy, and beautiful environment accompanied by physical and physical cleanliness that shows faith and transcendence.

e. Performing acts of amar ma'ruf and nahi munkar in the face of tyranny, greed; and engineering and policies. Manga, rah, influence, and cause environmental damage and exploitation of natural resources that cause destruction, damage, and injustice in life.

f. Working together and praxis actions with various parties, both individuals and collectives to maintain the balance, preservation and safety of the environment, as well as the avoidance of environmental damage as a manifestation of the attitude of devotion and caliphate in carrying out the mission of life on this earth for the salvation of life in the world and the hereafter.

In terms of disaster, in addition to these positive perspectives, responsiveness to disasters is also a spirit of righteous deeds, as well as the realization of the character values of Muhammadiyah in the form of mutual cooperation and solidarity [16].

The dynamic character values in the disaster respons are the major social capital in the future development of Muhammadiyah. Muhammad Fuad had seen the grassroots energy dynamism as one of the important milestones in the sustainability of Muhammadiyah going forward. Fuad wrote "the internal dynamic has been a reliable source of grassroots energy that has been proposed by the Muhammadiyah's continuity and growth, the movement of other problems in its role as a major player civil society [17].

\section{CONCLUSION}

In managing the environment, Theology of Muhammadiyah places the environment in the framework of parallels, in which the circulation of rights and obligations at the same time, moves and dialogues in the bonds of relations. humans are obliged to prosper and preserve it. (al-biah wa al-nasu fi nafs al-martabah huquqan wa wajibat)

Secondly, the treatment of the environment is not merely placing it in the dictum of daruriyyah which fulfills the five basic principles in Islamic law (maqasid syariah), but becomes an expression of human unity in Allah. When laying humans and the environment in alignment (both bearing the status of al-khalq) in the presence of Allah the Khaliq, submission in the shadows of revelation is absolutely put forward. (al-biah wa al-nasu khalqun $f i$ tauhid al-khaliq).

Third, the environment presents a body's unity for humans. So that everything that arises from the attitude and response to the environment becomes a common obligation. Maintenance and preservation are shared responsibilities. In fact, if a disaster arises from the environment, where the community becomes a victim, then other communities must be moved to help on the basis of a sense of humanity.

As a shared obligation in environmental preservation, unity in feelings and affinity makes one human being with other humans, especially those affected by calamity, more empathetic and help others with the best level of assistance ability that can be cultivated. (Ittihad al-Nas fi Masuliyyati a-Biah wa al-Hill 'an Musykilatiha). This makes Muhammadiyah change the decision, from a theoretical understanding of environmental preservation (Hifz al-Biah) to an active and practical attitude.

\section{ACKNOWLEDGMENT}

The author thanks the head of the Muhammadiyah University of Surabaya for financial support in the process of writing and presenting this article. Specifically, to the Head of the Islamic Family Law Program Gandhung Fajar Panjalu, Dean and his Deputy of the Islamic Faculty Isa Anshori and Arin Setyowati, and Dede Nasrullah, the Author expresses his deep gratitude for any helps and facilities so far.

\section{REFERENCES}

[1] A. K. A. Noor Naemah Abdul Rahman and Ridzwan Ahmad, Eds., Maqasid al-Shari'ah ; Konsep dan Pendekatan. Kuala Lumpur Malaysia: Jabatan Ushul Fiqh Akademi Pengajian Islam Universiti Malaysia, 2016. 
Keagamaan, vol. 16, no. 2, pp. 337-352-352, Dec. 2016.

Available:https://ekonomi.kompas.com/read/2013/03/1 8/02561284/perebutan.kian.sengit?page=all. [Accessed: 21-Nov-2019].

[3] R. Griffiths and W. Houston, Water: The Final Resource: How the Politics of Water Will Affect the World, 1 edition. Petersfield: Harriman House Publishing, 2008.

[4] Majelis Tarjih dan Tajdid Pimpinan Pusat Muhammadiyah, Himpunan Putusan Tarjih Muhammadiyah, 3rd ed. Yogyakarta: Suara Muhammadiyah, 2018.

[5] Ahmad Khoirul Fata, "Teologi Lingkungan Hidup Dalam Perspektif Islam," Ulul Albab Jurnal Studi Islam, vol. 15, no. 2, pp. 131-147, 2014.

[6] A. Roswantoro, "Refleksi Filosofis atas Teologi Islam Mengenai Lingkungan dan Pelestariannya," AlTahrir: journal of Islamic Thought, vol. 12, no. 2, pp. 219-238, Oct. 2016.

[7] R. J. Jacobus, "Understanding Environmental Theology: A Summary for Environmental Educator," The Journal of Environmental Education, vol. 35, no. 3, pp. 35-42, Apr. 2004.

[8] Abdul Quddus, "Ecothelogy Islam ; Teologi Konstruktif Atasi Krisis Lingkungan," Ulumuna Jurnal Studi Keislaman, vol. 16, no. 2 (nd), pp. 311-416.

[9] M. Maftukhin, "TEOLOGI LINGKUNGAN PERSPEKTIF SEYYED HOSSEIN NASR,” Dinamika Penelitian: Media Komunikasi Penelitian Sosial
[10] Ahmad Najib Burhani, Muhammadiyah Berkemajuan Pergeseran Dari Puritanisme Ke Kosmopolitanisme. Bandung: Mizan, 2016.

[11] Majelis Ulama Indonesia, Himpunan Fatwa MUI Sejak 1975. Jakarta: Erlangga, 2011.

[12] G. S. M. Mawardi and Miftahulhaq, Akhlaq Lingkungan ; Panduan Berperilaku Ramah Ligkungan. Jakarta: Kementerian Lingkungan Hidup RI dan Majelis Lingkungan Hidup PP Muhammadiyah, 2011.

[13] Asjmuni Abdurrahman, Manhaj Tarjih Muhammadiyah; Metodologi Dan Aplikasi, IV. Yogyakarta: Pustaka Pelajar, 2012.

[14] M.B Hooker, Indonesian Islam Social Change Through Contemporary Fatwa. Australia: Allen \& Unwin, 2003.

[15] dkk Asjmuni Abdurrahman, Pedoman Hidup Islami Warga Muhammadiyah : Keputusan Muktamar Muhammadiyah Ke-44 Tahun 2000 di Jakarta, IX. Yogyakarta: Suara Muhammadiyah, 2018.

[16] Mahsun, Muhammadiyah Sebagai Gerakan Tajrid Dan Tajdid, 3rd ed. Surabaya: Perwira Media Nusantara, 2017.

[17] M. FUAD, “Civil Society in Indonesia: The Potential and Limits of Muhammadiyah," Sojourn: Journal of Social Issues in Southeast Asia, vol. 17, no. 2, pp. 133-163, 2002. 